\title{
Clinical Characteristics of Cervical Toxoplasma Lymphadenitis
}

\author{
Ha Na Lee ${ }^{1}$, Seung Yeol Lee ${ }^{1}$, Jin Hyeok Jeong ${ }^{1}$, Yong Bae Ji ${ }^{1}{ }^{\mathbb{D}}$, \\ Kyueng-Whan Min ${ }^{2}$, and Kyung Tae ${ }^{1}$ \\ ${ }^{I}$ Departments of Otorhinolaryngology-Head and Neck Surgery, ${ }^{2}$ Pathology, College of Medicine, Hanyang University, Seoul, Korea
}

\author{
경부 톡소플라즈마 림프절염의 임상적 고찰 \\ 이하나 ${ }^{1} \cdot$ 이승열 ${ }^{1} \cdot$ 정진혁 $^{1} \cdot$ 지용배 ${ }^{1} \cdot$ 민경환 $^{2} \cdot$ 태 경 $^{1}$ \\ 한양대학교 의과대학 이비인후-두경부외과학교실, ${ }^{1}$ 병리학교실 ${ }^{2}$
}

\author{
Received September 18, 2020 \\ Revised November 4, 2020 \\ Accepted November 27, 2020 \\ Address for correspondence \\ Yong Bae Ji, MD, PhD \\ Department of Otolaryngology- \\ Head and Neck Surgery, \\ College of Medicine, \\ Hanyang University, \\ 222 Wangsimni-ro, Seongdong-gu, \\ Seoul 04763, Korea \\ Tel $+82-2-2290-8585$ \\ Fax $+82-2-2293-3335$ \\ E-mail jyb20000@hanyang.ac.kr
}

Background and Objectives Toxoplasmosis is a disease caused by an intracellular parasite, Toxoplasma gondii. There has been only a few studies done on cervical toxoplasma lymphadenitis, and this study was performed to evaluate its clinical characteristics and outcomes.

Subjects and Method We retrospectively reviewed the patients diagnosed with cervical toxoplasma lymphadenitis from January 2010 to December 2019. We investigated clinical pathologic findings, treatment and clinical outcomes.

Results Enrolled in the study were 21 patients who were confirmed with typical pathologic findings in an excisional biopsy (16/21) and core needle biopsy $(5 / 21)$. Nine patients were male and 12 patients were female, with the mean age of $46.1 \pm 13.59$ (19-70). All patients complained of neck masses and $5(23.8 \%)$ patients showed pain or tenderness. Only one (4.8\%) patient had mild fever. Fine needle aspiration cytology was performed in 5 patients, with no resulting pathognomonic outcomes in any one of the patients. CT scan was performed in 15 patients, with $8(53.3 \%)$ patients showing multiple nodal enlargements but $7(46.6 \%)$ patients showing a single enlarged lymph node. The most frequently involved location was level I (53.3\%), followed by level II (46.6\%), level V (46.6\%), level III (40.0\%), and level IV (20.0\%). The serologic test for toxoplasma revealed positive $\operatorname{IgG}(100 \%)$ and $\operatorname{IgM}(85.7 \%)$. Treatments were excision only $(61.9 \%)$ and excision with pharmacologic treatment using sulfonamide or pyrimethamine (38.1\%). There was no case of recurrence after treatment.

Conclusion Cervical toxoplasma lymphadenitis can be diagnosed by biopsy but needle aspiration has little role. It shows favorable clinical outcomes after treatment.

Korean J Otorhinolaryngol-Head Neck Surg 2021;64(12):901-5

Keywords Lymphadenitis; Lymph node; Parasite; Toxoplasma.

\section{서 론 \\ 톡소플라즈모시스(Toxoplasmosis)는 세포 내 기생충의 하 나인 톡소포자충(Toxoplasma gondii)에 의해 발생하는 전}

This is an Open Access article distributed under the terms of the Creative Commons Attribution Non-Commercial License (https://creativecommons.org/licenses/by-nc/4.0) which permits unrestricted non-commercial use, distribution, and reproduction in any medium, provided the original work is properly cited.
세계적인 감염성 질환으로 조류, 돼지 등의 날근육의 섭취, 고 양이 분비물에 오염된 난포낭의 섭취, 수혈, 실험실 감염, 장기 이식, 태반 내 감염 등의 경로로 감염된다. 대부분의 경우 감 염 시 증상이 없거나 비특이적으로 일부에서 주로 경부 림프 종대 소견을 보인다. 따라서 경부 종물로 내원한 환자들에 있 어서 임상의사가 초기에 의심하기는 쉽지 않다. 하지만 드물 게 경부 림프절염 이외에도 폐렴, 수막뇌염, 심근염, 망막맥락 
염, 중추신경계 감염 등의 심각한 감염을 일으킬 수도 있는 것으로 보고되고 있다. ${ }^{1)}$ 톡소플라즈마 림프절염의 진단에는 초기 연구들에서는 항체 분석을 사용하였고, 이를 기반으로 유병률을 평가하였다. ${ }^{2-6)}$ 전 세계적으로 $75 \%$ 에서 항체 양성 률을 보인다고 알려져 있으며, 이는 나라마다 큰 편차를 보여 중남미에서는 $80 \%$ 이상, 유럽에서는 $40 \%$ 60\%, 미국에서는 $35 \%$ 이상의 항체 양성률을 보인다. 우리나라에서 보고된 유 병률은 1.9\% 9.6\% 정도로, 다른 국가에 비해 상대적으로 낮 은 것으로 생각되나 소규모 연구이고 최근 급속한 해외 여행 의 증가, 애완동물 사육 및 육류 중심으로의 식습관 변화로 점차 유병률이 더 높을 수 있다고 생각되고 있다.8. 하지만 국 내에는 증례 보고만 수차례 있을 뿐 톡소플라즈마 림프절염에 대한 종합적 보고가 없으며 세계적으로도 드문 실정이다.,10)

이에 본 연구는 경부 톡소플라즈마 림프절염으로 진단되고 치료받았던 환자들을 대상으로 임상적 특성을 알아보고 진 단 방법에 따른 소견과 치료 및 그 결과에 대해 분석하여 향 후 빠른 진단 및 치료에 도움을 주고자 시행되었다.

\section{대상 및 방법}

2010년 1월 2019년 12월까지 한양대학교 구리병원에 경부 종물을 주소로 내원하여 시행한 조직병리검사에서 톡소플라 즈마 림프절염으로 진단된 환자를 대상으로 의무기록을 후향 적으로 조사하였다. 조직검사상 톡소플라즈마 림프절염으로 진단되었으나 액와부 및 서혜부에서 발생한 3예의 두경부 이 외 부위는 연구에서 제외하였으며, 3 예의 환자 의무기록이 불 충분한 경우도 역시 연구 대상에서 제외하였다.

환자의 성별, 진단 당시 연령, 증상 및 징후, 임상병리학적 검사 결과, 진단 방법에 대해 조사하였으며, 영상의학적 특성 을 분석하기 위해 경부 전산화단층촬영에서 나타나는 침범 된 림프절의 크기와 다발성, 조영되는 양상, 침범되는 위치를 조사하였다. 톡소플라즈마에 대한 $\operatorname{IgM}$ 및 $\mathrm{IgG}$ 항체 검사 결 과를 조사하였으며, 치료방법 및 효과, 그리고 합병증 유무 와 예후에 대해 조사 분석하였다. 본 연구는 본원의 기관생 명윤리위원회(Institutional Review Board)의 승인을 받았다 (HUGH-2020-08-006).

\section{결 과}

\section{환자의 특성 및 임상 증상}

총 21명의 경부 톡소플라즈마 림프절염이 포함되었다. 21명 중 남성은 9명(42.8\%), 여성은 12명(57.2\%)이었으며, 내원 당시 평균 나이는 $46.1 \pm 13.59$ 세였다. 가장 어렸던 환자는 19세였고
가장 나이가 많았던 환자는 70세였으며, 19예(90.5\%)가 30세 이상이었다. 모든 환자군에서 병원 내원 당시 경부 종물을 호 소하였다. 경부 통증이나 압통이 동반된 경우는 5명(23.8\%)이 있었으며, 발열이 1 명(4.8\%)에서 동반되었다. 발병부터 치료 까지 걸린 시간은 평균 $56 \pm 89.5$ 일이었고, 일부에서 경미한 혈액학적 이상 소견을 보였으나 특이적 소견은 관찰되지 않 았다(Table 1).

\section{영상의학적 소견}

영상의학적 검사로 15 명(71.4\%)에서 경부 전산화단층촬영 이 시행되었고, 그 외 6명(28.6\%)에서는 영상 검사 없이 조직 병리검사만 단독으로 시행되었다. 경부 전산화단층촬영에서 15 명 중 7명(46.6\%)에서 림프절 종대가 단발성으로 관찰되었 고, 8 명(53.3\%)에서는 다발성 림프절 종대가 관찰되었다. 영상 소견상 모든 환자에서 균질한 조영증강을 보이는 원형의 림 프절 종대로 관찰되었으며, 림프절 주변 침윤(perinodal infiltration)은 8명(53.3\%)에서 확인되었다. 대상 환자 15 명 중 최대 림프절의 평균 크기는 $18.9 \pm 7.21 \mathrm{~mm}(9$ 34)였다.

침범된 림프절은 level I(53.3\%), level V(46.6\%), level II (46.6\%), level III(40.0\%), level IV(20\%) 순이었으며, level VI 침범이 발견된 증례는 없었다. 최대 크기의 림프절이 관찰되

Table 1. Demographics and clinical characteristics of patients with cervical toxoplasma lymphadenitis

\begin{tabular}{|c|c|}
\hline Variables & n (\%) \\
\hline Gender (M:F) & $9: 12$ \\
\hline Age & $46.1 \pm 13.59(19-70)$ \\
\hline$<30$ & $2(9.5)$ \\
\hline $31-40$ & $4(19.0)$ \\
\hline $41-50$ & $7(33.3)$ \\
\hline$>50$ & $8(38.1)$ \\
\hline \multicolumn{2}{|l|}{ Symptoms } \\
\hline Neck mass & $21(100)$ \\
\hline Tenderness & $5(23.8)$ \\
\hline Fever & $1(4.8)$ \\
\hline Duration of symptom (days) & $56.0 \pm 89.5$ \\
\hline \multicolumn{2}{|l|}{ Laboratory findings } \\
\hline Leukocytosis (WBC > 10000) & $0(0)$ \\
\hline Anemia $(\mathrm{Hb}<12)$ & $2 / 18(11.1)$ \\
\hline Thrombocytopenia (<150 k) & $2 / 18(11.1)$ \\
\hline Lymphocytosis (> 44\%) & $4 / 18(22.2)$ \\
\hline Monocytosis (>9\%) & $2 / 18(11.1)$ \\
\hline Eosinophilia (> 5\%) & $1 / 17(5.8)$ \\
\hline Toxoplasma IgG (+) & $10 / 10(100)$ \\
\hline Toxoplasma IgM (+) & $6 / 7(85.7)$ \\
\hline
\end{tabular}

WBC: white blood cell, $\mathrm{Hb}$ : hemoglobin, IgG: immunoglobulin G, IgM: immunoglobulin $M$ 
는 위치는 level V(46.6\%)가 가장 많았고 level II(26.7\%), level $\mathrm{I}(20.0 \%)$ 순이었다(Fig. 1).

\section{조직병리학적 소견}

조직병리학적 검사로 전체 대상환자 21명 중 7명(33.3\%) 환 자에서 세침흡인검사(fine needle aspiration cytology)를 우 선 시행하였으나 톡소플라즈마 림프절염으로 진단된 경우는 없었고, 반응성 증식 2예, 비정형 림프세포 3예, 비진단적 2예 로 보고되었다. 이 환자들을 포함하여 총 16 명(76.2\%)에서 절 제생검이 시행되었고, 나머지 5명(23.8\%)은 중심부 바늘생검 이 시행되었다. 조직병리학적 소견에서 반응성 여포 증식, 상 피양 조직구의 군집 및 다수의 단핵구양 $\mathrm{B}$ 세포의 국소적 동 모양 확장 등의 특징적인 소견을 보였다(Fig. 2).

\section{임상 병리학적 소견}

조직학적으로 진단된 환자 중 7명의 환자에서 톡소플라즈 마에 대한 IgM, 10명의 환자에서 IgG 검사가 enzyme-linked immunosorbent assay(ELISA, 효소결합 면역흡착검사)를 이용하여 시행되었다. $\operatorname{IgM}$ 은 6/7명(85\%)에서 $\operatorname{IgG}$ 는 $10 / 10$ 명 (100\%)에서 양성을 보였다.

\section{치료 및 예후}

치료는 절제생검만 시행한 경우가 13명(61.9\%)이었다. 중심 부 바늘생검으로 진단된 경우, 다발성 급성 림프절 종대 또는
통증이나 발열이 있었던 경우 sulfonamide를 8명(38.1\%)에서 투여하였으며, 이 중 1명은 sulfonamide에 알레르기 반응이 있어 pyrimethamine을 처방하였다. 전체 환자 중 재발되어 다시 방문한 경우는 없었으며, 약물 치료를 시행한 환자 모두 추적 관찰에서 재발 소견은 없었다.

\section{고 찰}

톡소플라즈마 림프절염은 대부분의 경우 감염 시 증상이 없거나 비특이적이며, 주로 초기 증상으로 경부 림프 종대 소 견을 보인다고 알려져 있다. 드물게 경부 림프절염 이외에도 폐렴, 수막뇌염, 심근염, 망막맥락염, 중추신경계 감염 등의 심각한 감염을 일으킬 수도 있는 것으로 보고되고 있다.' 하 지만 본 연구에서는 모든 환자가 내원 당시 경부 종물을 주 소로 내원하였으며, 1명(4.76\%)에서만 발열을 동반하였고 압 통을 동반한 경우도 5 예(23.8\%)로 대부분의 환자에서는 무 통성 림프절 종대만 관찰되었다.

영상의학적 소견에서는 모든 환자에서 균질한 조영증강을 보이는 원형의 림프절 종대로 관찰되었으며 괴사가 동반되는 경우는 없었다(Fig. 3). 침범되는 림프절은 level I, II, V가 많 았지만 대체로 경부 전반에 걸쳐 발생하였으며, 이하선 림프 절을 침범한 경우가 1 예 있었다.

21명 중 16명(76.2\%)은 절제생검, 나머지 5명(23.8\%)은 중 심부바늘생검을 통해 톡소플라즈마 림프절염으로 진단되었
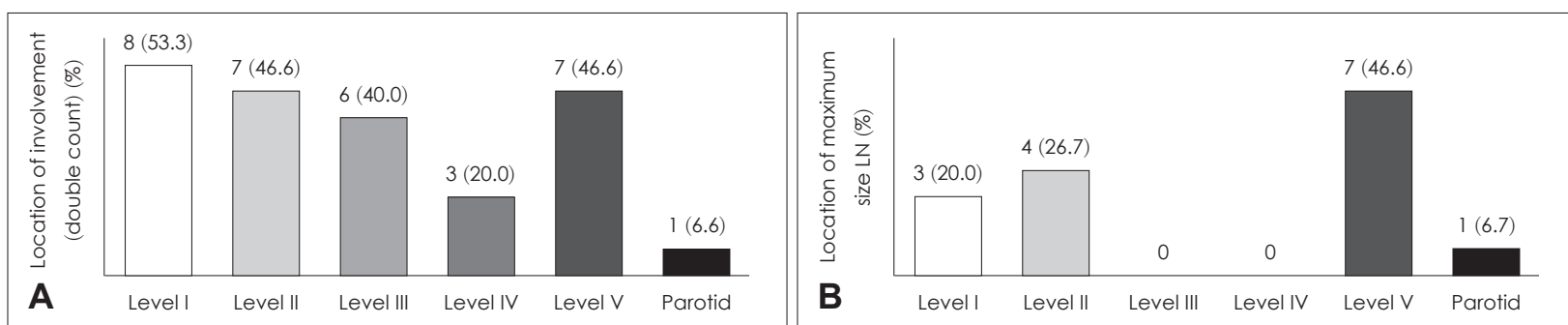

Fig. 1. Distribution of toxoplasma lymphadenitis. Location of $L N$ involvement (double counted) (A). Location of maximum size LN (B). LN: lymph node.
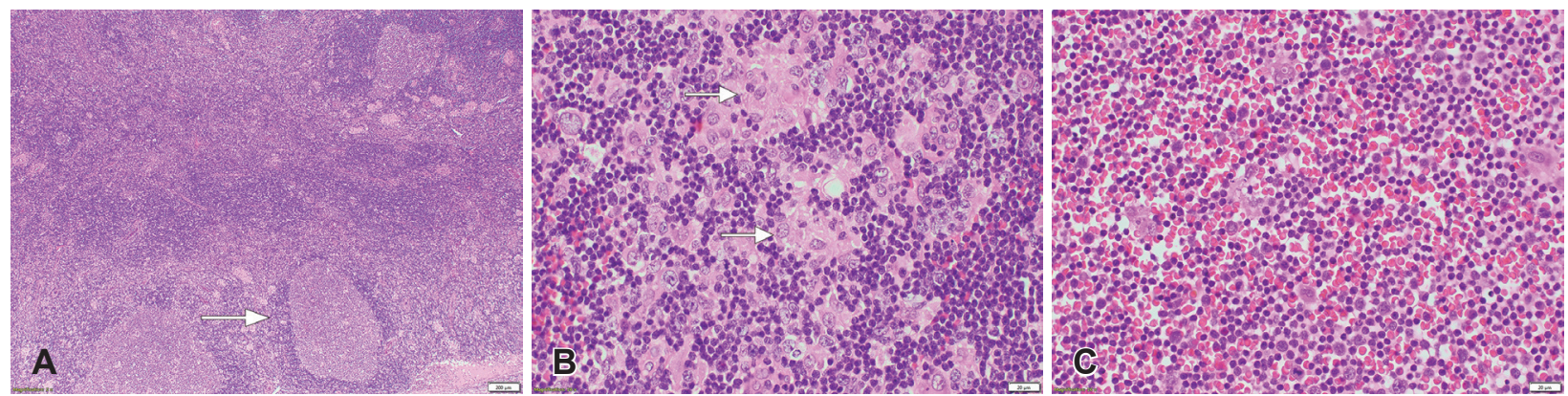

Fig. 2. Histopathologic finding of toxoplasma lymphadenitis. Reactive follicular hyperplasia (arrow) (H\&E stain, $\times 40)(A)$. Clusters of epitheloid histiocytes in the hyperplastic follicles (arrows) (H\&E stain, $\times 400)(B)$. Sheet of monocytoid B cell in extramarginal zone area (H\&E stain, $\times 400)(C)$. H\&E: hematoxylin and eosin. 

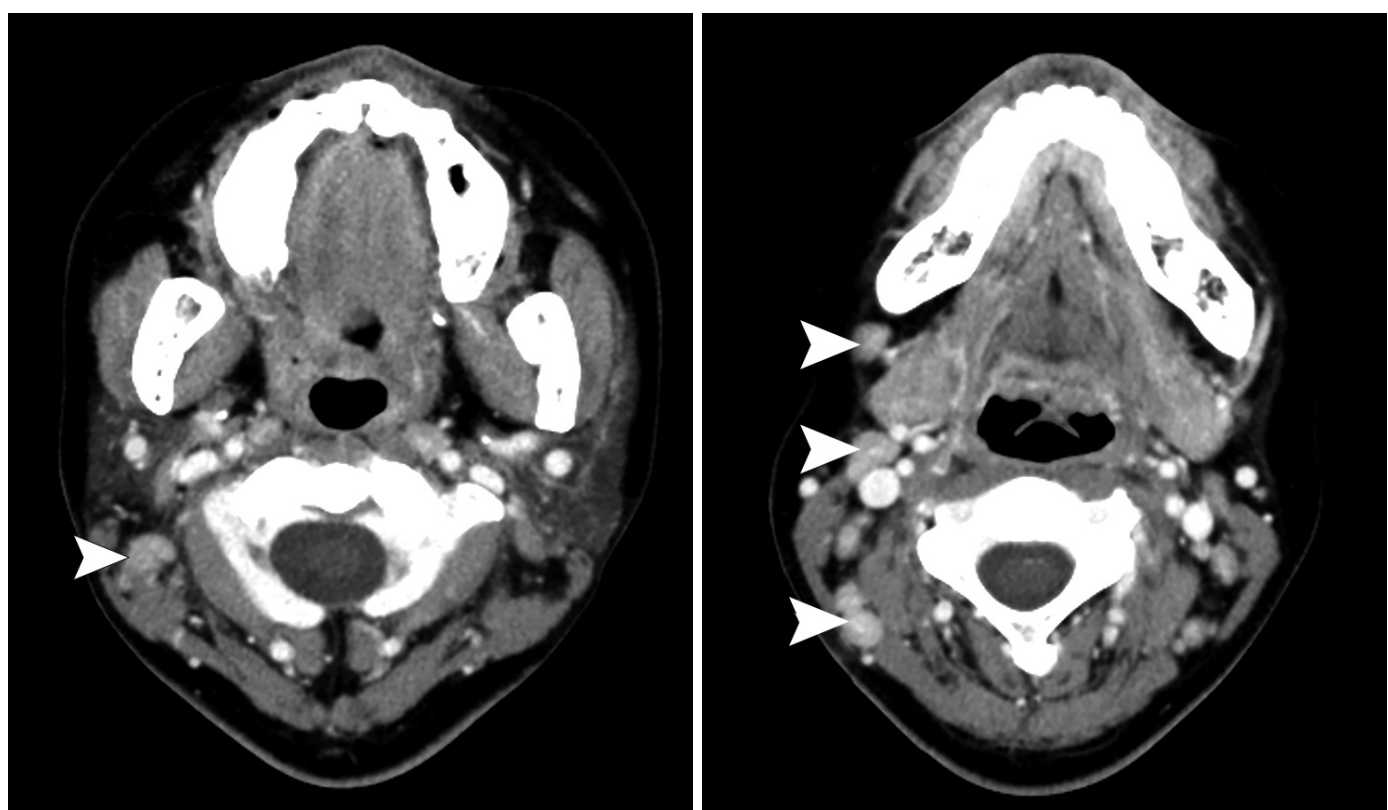

Fig. 3. Computed tomographic findings of cervical toxoplasma lympadenitis. Multiple enlarged round lymph nodes with homogeneous enhancement were noted in neck level II-V without necrotic change (arrowheads).

다. 이 중 7명(33.3\%)에서 세침흡인생검을 우선 시행하였으나 반응성 증식 2예, 비정형 림프세포 3예, 비진단적 2예로 보고 되어 톡소플라즈마 림프절염 진단에서 세침흡인검사의 역할 은 제한적일 것으로 사료된다. 반면 중심부바늘생검을 시행 한 5 예는 모두 톡소플라즈마 림프절염으로 진단되어 절제생 검을 대체할 수 있는 가능성을 확인하였다. 톡소플라즈마 림 프절염에 대한 세포흡인검사의 역할에 대한 몇몇 연구에 따 르면 톡소포자원충 또는 난포낭이 확인되는 매우 드문 경우 를 제외하고는 다른 여러가지 원인에 의해서 발생하는 반응 증식성 림프절염과 세포학적으로 구분하기 어려운 것으로 보고하고 있다. ${ }^{11,12)}$

톡소플라즈마 림프절염의 진단조직병리학적 소견으로는 3 가지 특징적인 소견을 보이는데, 첫째, 다수의 중심 아세포 (centroblasts), 유사 분열(mitoses) 및 가염성(tingible) 조직구 가 두드러지는 반응성 여포 증식을 보인다(Fig. 2A). 둘째, 여 포의 배중심을 둘러싸고 침투하는 상피양 조직구가 주변과 잘 경계되지 않는 군집 또는 육아종을 이룬다(Fig. 2B). 셋째 는 다수의 단핵구양 $\mathrm{B}$ 세포가 림프절 주위 또는 림프절 내에 서 작거나 큰 세포 집단으로 나타난다. 단핵구양 세포는 중간 크기이며, 중간 정도의 투명한 세포질, 그리고 중심 타원형의 불규칙한 핵 윤곽 및 불분명한 핵소체(nucleoli)를 가지고 유사분열이나 괴사는 나타나지 않는다. 여포 사이 공간에는 과활성화된 세정맥, 형질세포 과다증식, 그리고 활성화된 림 프구들이 관찰된다(Fig. 2C). ${ }^{13,14)}$ 이와 같은 특징적인 조직병 리학적 소견은 본 연구의 증례에서도 동일하게 확인되었다.
$\operatorname{Lin}$ 과 $\mathrm{KuO}^{15}$ 는 위와 같은 3 가지 특징이 모두 관찰되는 경우 91.3\%의 높은 특이도로 톡소플라즈마 림프절염을 진단할 수 있고, 이 경우에 혈청학적 검사를 하면 약 80\% 90\%에서 항 체 양성률을 보인다고 보고하였다.

톡소플라즈마의 혈청학적 검사법은 항톡소플라즈마 $\operatorname{IgM}$, $\operatorname{IgG}$ 항체를 검출하며, 이때 ELISA법을 많이 사용한다. IgM 항체는 감염 1 주 이내에 나타나 3 개월 후까지 양성 반응을 보여 최근 감염을 의미하며, $\mathrm{IgG}$ 항체는 감염 후 2,3 주 후에 양성 반응을 보이며 평생 지속된다. 그러나 $\operatorname{IgG}$ 항체가 음성 에서 양성으로 바뀌거나 3주 간격을 두고 4배 이상 증가한 경우에도 급성기 감염으로 진단할 수 있다. ${ }^{16)}$ 본 연구에서는 $\operatorname{IgM}$ 항체는 검사를 시행한 7명 중 6명(85.7\%)에서 양성을 보 였고, $\operatorname{IgG}$ 항체는 시행한 10 명 모두에서 양성을 보였다.

경부 톡소플라즈마 림프절염의 치료는 무증상인 경우 치 료가 필요하지 않으며, 증상이 있는 경우에만 증상에 대한 대 증적 요법을 시행한다고 알려져 있다. 따라서 본 연구에서도 국소적 림프절염으로 나타나 절개생검으로 대부분의 병변을 제거하거나 경미한 림프절 종대만을 보인 증례들은 확진 후 추가적인 치료는 시행되지 않았다. 하지만 톡소플라즈마 림 프절염의 예후는 환자의 면역기능에 매우 관련이 깊다고 보 고되고 있다. ${ }^{17)}$ 면역체계가 약화된 사람, 특히 후천적 면역결 핍증 환자에서는 심근염, 폐렴, 중추신경계 감염 등 심각한 염증을 일으키는 경우가 Marra ${ }^{18)}$ 에 의해 보고된 바 있으며, Sano 등 19 은 톡소플라즈마로 인한 심낭염 22예를 보고하였고, 특히 이 중 15 예는 면역 기능이 정상이었기에 경과 관찰에 주 
의를 기울여야 한다고 주장하였다. 따라서 면역기능이 저하된 경우나 증상이 심한 급성 감염의 경우에 있어서 macrolide 항생제 단독요법 또는 sulfonamide, pyrimethamine 병용요 법을 고려하며, 면역기능이 정상인 경우 2주간 증상 소실 후 추가적인 약물치료를 시행하고, 면역기능 저하자에는 4 6주 간 추가적인 약물치료를 시행하는 것이 시도되고 있다. ${ }^{20)}$ 본 연구에서는 면역저하를 보인 환자는 없었고, 13명(61.9\%)에서 절제생검만 시행하였다. 하지만 다발성 림프 종대 소견 또는 압통을 동반한 8명(38.1\%)에서는 sulfonamide(400 1600 $\mathrm{mg} / \mathrm{day})$ 또는 pyrimethamine 유도용량 $(100 \mathrm{mg})$, 이어서 유 지용량 $(25 \sim 50 \mathrm{mg})$ 을 4주간 투여하였다. 이후 추적 관찰된 환자중에 재발 소견을 보인 환자는 없었다.

결론적으로 경부 톡소플라즈마 림프절염은 단순 절제 또는 약물투여로 양호한 예후를 보이는 것으로 보인다. 하지만 본 연구 대상에는 관찰되지 않았지만 면역저하 환자에서 치명 적인 감염을 유발할 수도 있다는 보고가 있으므로, 경부 종 물을 주소로 내원한 환자에서 톡소플라즈마 림프절염이 감 별진단에 포함되어야 하고, 진단 후 적절한 치료와 함께 추적 관찰해야 할 것으로 사료된다. 진단을 위해서는 절제생검이나 중심부바늘생검이 유용한 것으로 보이며 세침흡인검사는 진 단에 한계가 있는 것으로 사료된다.

\section{Acknowledgments}

None.

\section{Author Contribution}

Conceptualization: Yong Bae Ji. Data curation: Ha Na Lee, Seung Yeol Lee, Kyueng-Whan Min. Formal analysis: Ha Na Lee, Seung Yeol Lee. Methodology: Yong Bae Ji, Kyung Tae. Visualization: Ha Na Lee. Writing - original draft: Ha Na Lee, Seung Yeol Lee. Writing — review \& editing: Kyueng-Whan Min, Yong Bae Ji, Jin Hyeok Jeong, Kyung Tae.

\section{ORCID}

Yong Bae Ji

https://orcid.org/0000-0002-0182-7865

\section{REFERENCES}

1) Hill D, Dubey JP. Toxoplasma gondii: Transmission, diagnosis and prevention. Clin Microbiol Infect 2002;8(10):634-40.

2) Montoya JG, Parmley S, Liesenfeld O, Jaffe GJ, Remington JS. Use of the polymerase chain reaction for diagnosis of ocular toxoplasmosis. Ophthalmology 1999;106(8):1554-63.
3) Liesenfeld O, Press C, Flanders R, Ramirez R, Remington JS. Study of Abbott Toxo IMx system for detection of immunoglobulin $\mathrm{G}$ and immunoglobulin M Toxoplasma antibodies: Value of confirmatory testing for diagnosis of acute toxoplasmosis. J Clin Microbiol 1996;34(10):2526-30.

4) Sever JL, Ellenberg JH, Ley AC, Madden DL, Fuccillo DA, Tzan $\mathrm{NR}$, et al. Toxoplasmosis: Maternal and pediatric findings in 23,000 pregnancies. Pediatrics 1988;82(2):181-92.

5) Montoya JG, Remington JS. Studies on the serodiagnosis of toxoplasmic lymphadenitis. Clin Infect Dis 1995;20(4):781-9.

6) Liesenfeld O, Montoya JG, Tathineni NJ, Davis M, Brown BW Jr, Cobb KL, et al. Confirmatory serologic testing for acute toxoplasmosis and rate of induced abortions among women reported to have positive Toxoplasma immunoglobulin M antibody titers. Am J Obstet Gynecol 2001;184(2):140-5.

7) Choi WY. Diagnosis and epidemiology of toxoplasmosis in Korea. Korean J Parasitol 1990;28 Suppl:41-4.

8) Lee SH, Pak BG. Dye Test for Toxoplasmosis to normal population in Pusan. Korean J Ophthalmol 1971;12(1):1-6.

9) Nam IC, Cho YJ, Jun BC, Cho KJ. Toxoplasmic lymphadenitis of the head and neck region. Korean J Otorhinolaryngol-Head Neck Surg 2015;58(5):341-3.

10) Kim YH, Lee JH, An YH, Kim KH. Three cases of Toxoplasma lymphadenitis arising in the posterior neck: Case report and literature review. Korean J Otolaryngol 2006;49(1):102-5.

11) Gupta RK. Fine needle aspiration cytodiagnosis of toxoplasmic lymphadenitis. Acta Cytol 1997;41(4):1031-4.

12) Zaharopoulos P. Demonstration of parasites in Toxoplasma lymphadenitis by fine-needle aspiration cytology: Report of two cases. Diagn Cytopathol 2000;22(1):11-5.

13) Dorfman RF, Remington JS. Value of lymph-node biopsy in the diagnosis of acute acquired toxoplasmosis. N Engl J Med 1973; 289(17):878-81.

14) Eapen M, Mathew CF, Aravindan KP. Evidence based criteria for the histopathological diagnosis of toxoplasmic lymphadenopathy. J Clin Pathol 2005;58(11):1143-6.

15) Lin MH, Kuo TT. Specificity of the histopathological triad for the diagnosis of toxoplasmic lymphadenitis: Polymerase chain reaction study. Pathol Int 2001;51(8):619-23.

16) McCabe RE, Brooks RG, Dorfman RF, Remington JS. Clinical spectrum in 107 cases of toxoplasmic lymphadenopathy. Rev Infect Dis 1987;9(4):754-74.

17) Montoya JG, Liesenfeld O. Toxoplasmosis. Lancet 2004;363(9425): 1965-76.

18) Marra CM. Central nervous system infection with Toxoplasma gondii. Handb Clin Neurol 2018;152:117-122.

19) Sano J, Saitoh H, Kobayashi Y, Ikeda M, Kodani E, Takayama M, et al. Toxoplasma pericarditis without immunosuppressant disorder detected by polymerase chain reaction of pericardial fluid: A case report. J Cardiol 2000;35(1):47-54.

20) Roth JA, Siegel SE, Levine AS, Berard CW. Fatal recurrent toxoplasmosis in a patient initially infected via a leukocyte transfusion. Am J Clin Pathol 1971;56(5):601-5. 